presented by the authors may have revealed leftward tongue retraction due to a right hemilingual weakness. Among the known causes of a geographic tongue, a fungal infestation from poor hygiene is frequent. This relatively immobile weakened tongue may predispose the patients to decreased spontaneous cleansing, which explains hemigeographic tongue from a contralateral cerebral stroke.

Author Response: Montserrat G. Delgado, Sergio Calleja, Oviedo, Spain: We thank Dr. Chang for the interest in on our NeuroImage ${ }^{1}$ and the valuable clinical contribution. In our daily clinical practice, a hemigeographic tongue is not a frequent epiphenomenon in patients with hemispheric stroke, in spite of the fact that fungal infestation is possible in these medical setting situations (both patients presented hemigeographic tongue while hospitalized due to acute ischemic stroke). After some months, while weakness persisted, the hemigeographic tongue disappeared in one patient; the second patient was lost to followup. As Dr. Chang explains, hemilingual weaknesses may be seen from contralateral cerebral strokes, but this is the first report on this disorder, to our knowledge, which suggests that the mechanism of hemigeographic tongue may be more complex. In this way, a CNS disorder may provoke an alteration of the secretion of certain trophic factors that could be implicated in the trigeminal trophic syndrome pathogenesis. $^{2,3}$

(C) 2016 American Academy of Neurology

1. Delgado MG, Calleja S. Teaching NeuroImages: Hemigeographic tongue following an acute ischemic stroke. Neurology 2016;87:e6-e7.

2. Rashid RM, Khachemoune A. Trigeminal trophic syndrome. J Eur Acad Dermatol Venereol 2007;21: 725-731.

3. Bove D, Lupoli A, Caccavale S, Piccolo V, Ruocco E. Dermatological and immunological conditions due to nerve lesions. Funct Neurol 2013;28:83-91.

\title{
CORRECTION
}

\section{Familial occurrence and heritable connective tissue disorders in cervical artery dissection}

In the article "Familial occurrence and heritable connective tissue disorders in cervical artery dissection" by S. Debette et al., ${ }^{1}$ there is an omission in table 4. The "Gene with mutation" for Patient 1 (ID: I) should have read "COL3A1, NM_000090.3:c.1618G>A (p.Gly540Arg)" rather than "COL3A1, p.Gly540Arg" as originally published. The authors regret the omission. In addition, the authors would like to clarify the following: Patient 2 (ID: II) had a G to A transition (NM_000090.3:c.2212G>A) resulting in a p.Gly738Ser substitution according to the HGVS nomenclature, corresponding to a Gly571Ser substitution in the legacy amino acid numbering for type III collagen. The HGVS codon number is obtained by adding 167 amino acids to the legacy number. The authors regret that only the legacy numbering had previously been mentioned.

\section{REFERENCE}

1. Debette S, Goeggel Simonetti B, Schilling S, et al. Familial occurrence and heritable connective tissue disorders in cervical artery dissection. Neurology 2014;83:2023-2031. 


\section{Neurology}

\section{Familial occurrence and heritable connective tissue disorders in cervical artery dissection}

Neurology 2016;87;2500

DOI 10.1212/WNL.0000000000003446

\section{This information is current as of December 5, 2016}

\section{Updated Information \&} Services

References

Permissions \& Licensing

Reprints including high resolution figures, can be found at: http://n.neurology.org/content/87/23/2500.full

This article cites 1 articles, 1 of which you can access for free at: http://n.neurology.org/content/87/23/2500.full\#ref-list-1

Information about reproducing this article in parts (figures,tables) or in its entirety can be found online at:

http://www.neurology.org/about/about_the_journal\#permissions

Information about ordering reprints can be found online:

http://n.neurology.org/subscribers/advertise

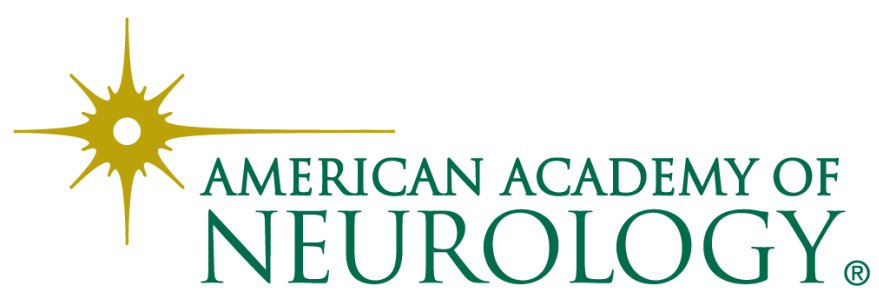

